\title{
RANTES in Exhaled Breath Condensate of Allergic Asthma Patients with Exercise-Induced Bronchoconstriction
}

\author{
Z. Zietkowski $^{a} \quad$ R. Skiepko ${ }^{a} \quad$ M.M. Tomasiak-Lozowska ${ }^{a} \quad$ B. Mroczko ${ }^{b}$ \\ M. Szmitkowski ${ }^{b} \quad$ A. Bodzenta-Lukaszyk ${ }^{a}$ \\ Departments of a Allergology and Internal Medicine and ${ }^{\mathrm{b}}$ Biochemical Diagnostics, Medical University of Bialystok, \\ Bialystok, Poland
}

\section{Key Words}

Airway inflammation · Asthma • Exercise-induced

bronchoconstriction - Exhaled breath condensate $\cdot$ RANTES

\begin{abstract}
Background: The response of asthmatics to exercise differs from that of healthy subjects, and the mechanisms responsible for exercise-induced bronchoconstriction (EIB) remain to be elucidated. Objectives: The aim of this study was to evaluate changes in RANTES levels in exhaled breath condensate (EBC) following intensive exercise in allergic asthmatics. Methods: The study was conducted in a group of 19 asthmatics (11 with EIB and 8 without EIB) and 7 healthy volunteers. Changes in the concentrations of RANTES in EBC induced during the $24 \mathrm{~h}$ after intensive exercise were determined. Moreover, these measurements were tested for possible correlations with the results of other tests commonly associated with asthma as well as with changes in airway inflammation after exercise. Results: In contrast to asthmatic patients without EIB and healthy controls, in asthmatics with EIB RANTES concentrations were statistically significantly increased in EBC collected during the first $24 \mathrm{~h}$ after an exercise test. There was a statistically significant correlation between the maximum increase in RANTES concentrations in
\end{abstract}

EBC after exercise and either baseline exhaled nitric oxide $\left(\mathrm{F}_{\mathrm{ENO}}\right)$ or bronchial hyperreactivity to histamine and an increase in serum eosinophil cationic protein or $\mathrm{F}_{\mathrm{ENO}} 24 \mathrm{~h}$ after exercise in the EIB asthmatics. Conclusions: The increase in RANTES in asthmatic airways, promoting the migration and activation of inflammatory cells including eosinophils, may play an important role in the upregulation of airway inflammation after EIB in asthmatic patients.

Copyright $\odot 2009$ S. Karger AG, Basel

\section{Introduction}

Evidence is accumulating that exercise-induced bronchoconstriction (EIB) is associated with eosinophilic airway inflammation, bronchial hyperreactivity (BHR), atopy and airway obstruction [1]. However, results related to the participation of inflammatory mediators in either the maintenance or induction of bronchoconstriction provoked by exercise are still conflicting [2].

Eosinophilic granulocytes are attracted and activated by chemokines, proteins of the cytokine family. Eosinophils initiate tissue damage via the release of cytotoxic substances like major basic protein, eosinophil cationic protein (ECP), eosinophil peroxidase and the autocrine production of chemokines, which cause a self-sustained

\section{KARGER}

Fax +41613061234 E-Mail karger@karger.ch www.karger.com (c) 2009 S. Karger AG, Basel

0025-7931/10/0806-0463\$26.00/0

Accessible online at:

www.karger.com/res
Z. Zietkowski, MD, $\mathrm{PhD}$

Department of Allergology and Internal Medicine

Medical University of Bialystok, Sklodowska Street 24A

PL-15 276 Bialystok (Poland)

Tel. +48 85746 8373, Fax +48 85746 8601, E-Mail z.zietkowski@wp.pl 
inflammatory process and chronic disease [3]. Eosinophils are the key effector cells in asthma [4], but their role in EIB is less clear and controversial.

Chemokines are a family of cytokines that are believed to be involved in the pathogenesis of asthma, possibly by recruiting leukocytes to the site of inflammation [5]. CCL chemokines, e.g. RANTES and eotaxin, have been implicated in the allergic inflammation in asthma by promoting the migration and activation of inflammatory cells, including eosinophils [6].

In asthmatic patients, increased expression of local and systemic CCL chemokines has been reported [7, 8]. In vitro studies have demonstrated that hyperosmolar stimuli induce the release of chemotactic mediators from human epithelial cells $[9,10]$. Eosinophil and neutrophil counts were also raised in bronchoalveolar lavage fluid in the late phase of EIB [11]. Yoshikava et al. [12] found a relationship between the severity of EIB and the percentage of eosinophils in sputum as well as the level of ECP in adult asthmatics, suggesting that the presence of sputum eosinophilia predicts airway responsiveness provoked by exercise. EIB, which is stimulated by the release of mediators mainly by mast cells, aggravates eosinophilic inflammation [1]. These findings suggest that eosinophils may play a major role in the severity of EIB in patients with asthma.

In our previous studies in asthmatic patients, plasma concentrations of RANTES were increased following EIB, possibly due to platelet activation [13]. In the present study, we aimed to determine the role of RANTES expression in the airways in the pathogenesis of EIB in asthmatics.

The study was performed on exhaled breath condensate (EBC). EBC samples were collected by cooling exhaled air - a noninvasive, easily performed and effort-independent, rapid procedure to obtain samples from the lower respiratory tract [14]. In earlier studies, Matsunaga et al. [15] reported that RANTES expression was upregulated in EBC of asthmatic airways.

The aim of this study was to evaluate RANTES levels and their changes following EIB in EBC of asthmatic patients, and to establish possible correlations of these measurements with parameters of airway inflammation.

\section{Patients and Methods}

\section{Patients}

The study involved a group of 19 mild allergic asthma patients. Asthma was diagnosed according to the criteria recommended by the Global Initiative for Asthma updated in 2002 [16]. The diag- nosis of allergic asthma was based on positive skin prick tests and a history of asthma and symptoms of allergic rhinitis following exposure to sensitizing allergens. All patients had been in a stable condition, and free from acute exacerbations and respiratory tract infections the previous 2 months. Patients with other factors possibly affecting exhaled nitric oxide $\left(\mathrm{F}_{\mathrm{ENO}}\right)$ levels (except for asthma and features of atopy or allergic rhinitis) were not included. In all the patients, tests were performed outside the pollen season. Prior to study entry, patients were allowed to take short-acting $\beta_{2}$-agonists. Asthmatic patients who had been treated with drugs other than $\beta_{2}$-agonists (e.g. inhaled steroids or anti-leukotrienes) in the past 3 months were excluded from the study. Before qualifying a patient for the exercise test, $\mathrm{F}_{\mathrm{ENO}}$ and total IgE levels were assessed, and skin prick tests to commonly encountered aeroallergens (e.g. house dust mites, trees, weeds, grasses, cat, Alternar$i a$ and Cladosporium), flow/volume spirometry and a bronchial provocation test (BPT) with histamine were performed in each asthmatic patient.

Seven healthy volunteers were also recruited for the study as a negative control. All of them underwent $\mathrm{F}_{\mathrm{ENO}}$, flow/volume spirometry and skin prick tests to common aeroallergens. Their forced expiratory volume in $1 \mathrm{~s}\left(\mathrm{FEV}_{1}\right)$ was $>80 \%$ of predicted. They were free of respiratory tract infections during the 2 months before study entry and from other significant illnesses known to affect $\mathrm{F}_{\mathrm{ENO}}$ levels. Asthma patients and healthy volunteers were nonsmokers and had not been passive smokers during the last year.

All asthmatic patients and healthy volunteers performed an exercise test on the bicycle ergometer.

\section{Study Protocol}

BPT with histamine was performed $24 \mathrm{~h}$ before and $24 \mathrm{~h}$ after exercise. EBC was collected before and $30 \mathrm{~min}$ after BPT with histamine, and before and after (10 and $30 \mathrm{~min}$, and 1, 6 and $24 \mathrm{~h}$ ) exercise. $\mathrm{F}_{\mathrm{ENO}}$ was measured before BPT with histamine, and before and $24 \mathrm{~h}$ after exercise. Serum ECP and peripheral blood eosinophilia were also assessed before and $24 \mathrm{~h}$ after exercise.

The study protocol was approved by the Ethics Research Committee of the Medical University of Bialystok (agreement No. R-I-003/80/2006). Informed consent was obtained from each patient entered into the study.

\section{Measurements}

$\mathrm{F}_{\mathrm{ENO}}$ was determined using the chemiluminescence technique (280i NO Analyzer; Sievers, Boulder, Colo., USA) at an expiratory flow of $50 \mathrm{ml} / \mathrm{s}$ according to recommendations of the American Thoracic Society (ATS) for online measurement of $\mathrm{F}_{\mathrm{ENO}}$ in adults [17].

Baseline spirometry was performed using a MasterScreen Pneumo PC spirometer (Jaeger, Hoechberg, Germany) according to ATS standards [18]. $\mathrm{FEV}_{1}$ was determined. Before the examination, the patients did not take any medication possibly affecting spirometry results.

A nonspecific BPT with histamine was carried out according to the method described by Ryan et al. [19]. Provocation was performed using a DeVilbiss nebulizer 646 (Viasys Healthcare, Hoechberg, Germany) at an air pressure of $0.15 \mathrm{MPa}$ linked to a dosimeter (Rosenthal-French, Baltimore, Md., USA). The results were presented as $\mathrm{PC}_{20} \mathrm{FEV}_{1}$ - the concentration of histamine which causes a decrease in $\mathrm{FEV}_{1}$ of exactly $20 \%$ in comparison to initial values. 
Table 1. Characteristics of asthmatic patient and healthy control groups

\begin{tabular}{|c|c|c|c|c|}
\hline \multirow[t]{2}{*}{ Characteristics } & \multicolumn{3}{|c|}{ Asthmatic patients } & \multirow{2}{*}{$\begin{array}{l}\text { Healthy } \\
\text { volunteers }\end{array}$} \\
\hline & with EIB & without EIB & $\mathrm{p}$ value & \\
\hline Patients, $\mathrm{n}$ & 11 & 8 & & 7 \\
\hline Sex, females/males & $7 / 4$ & $5 / 3$ & & $4 / 3$ \\
\hline Age, years & $27.36 \pm 7.50$ & $31.63 \pm 5.40$ & 0.19 & $28.40 \pm 4.90$ \\
\hline Duration of symptoms, years & $3.70 \pm 4.63$ & $4.12 \pm 3.54$ & 0.33 & \\
\hline Baseline $\mathrm{FEV}_{1}, \%$ of predicted & $95.63 \pm 18.54$ & $92.25 \pm 8.61$ & 0.63 & $106.85 \pm 9.73$ \\
\hline Maximum decrease in $\mathrm{FEV}_{1}$ after exercise, \% & $25.8 \pm 13.5$ & $3.6 \pm 1.9$ & 0.0003 & $0.71 \pm 3.2^{*, * *}$ \\
\hline $\log \mathrm{PC}_{20}$ histamine $\mathrm{FEV}_{1}, \mathrm{mg} / \mathrm{ml}$ & $-0.59 \pm 1.16$ & $-0.05 \pm 0.55$ & 0.24 & \\
\hline Blood eosinophil count, cells $/ \mathrm{mm}^{3}$ & $239 \pm 138$ & $157 \pm 66$ & 0.14 & $51 \pm 26^{*, * *}$ \\
\hline Serum ECP, $\mu \mathrm{g} / 1$ & $10.88 \pm 5.18$ & $7.64 \pm 1.63$ & 0.04 & $3.94 \pm 1.05^{*, * *}$ \\
\hline Serum total IgE, kU/l & $358 \pm 322$ & $171 \pm 69$ & 0.12 & $65 \pm 31^{* * * *}$ \\
\hline Baseline $\mathrm{F}_{\mathrm{ENO}}, \mathrm{ppB}$ & $98.90 \pm 55.37$ & $66.62 \pm 23.05$ & 0.21 & $18.00 \pm 5.59^{*, * *}$ \\
\hline Baseline RANTES, pg/ml & $8.76 \pm 0.93$ & $8.08 \pm 0.73$ & 0.11 & $3.56 \pm 0.76^{*}$ \\
\hline Positive skin prick test, $\mathrm{n}$ of patients & 11 & 8 & & 0 \\
\hline Mite/cat $/$ molds & $9 / 3 / 2$ & $7 / 2 / 2$ & & \\
\hline Seasonal & 4 & 3 & & \\
\hline
\end{tabular}

Data are presented as means $\pm \mathrm{SD}$. $\mathrm{PC}_{20}$ histamine $\mathrm{FEV}_{1}=$ provocative concentration of histamine that caused a $20 \%$ fall in $\mathrm{FEV}_{1} .{ }^{*} \mathrm{p}<0.05$ vs. patients with EIB, ${ }^{* *} \mathrm{p}<0.05$ vs. patients without EIB.

Exercise was performed on a bicycle ergometer for 9 min with a fixed workload adjusted to increase the heart rate to $85 \%$ of the maximum predicted for the age of each patient [20]. Basic spirometric parameters were recorded before and immediately after exercise, and 1, 5, 10, 15, 20, 60 min and $24 \mathrm{~h}$ after completion of exercise. Patients with maximum decrease in $\mathrm{FEV}_{1}>15 \%$ were considered to have EIB.

EBC was collected using a commercially available condenser (EcoScreen; Jaeger) according to the current ATS/European Respiratory Society guidelines [21]. All measurements were performed at the same time (between 8.00-10.00 a.m.) to avoid possible effects of the circadian rhythm on mediator concentrations in EBC. All patients were asked to refrain from eating and drinking before EBC sampling.

Exhaled air entered and left the chamber through one-way valves (inlet and outlet), thus keeping the chamber closed. Due to the low temperature inside the condensing chamber throughout collection, the expired air is cooled down and condenses. The temperature of collection was around $0^{\circ} \mathrm{C}$ [14]. Patients were instructed to breathe tidally for $10 \mathrm{~min}$ with a nose clip. The respiratory rate ranged from 15 to 20 breaths/min. Patients were asked to swallow their saliva periodically and to temporarily discontinue collection if they needed to cough. At the end of collection 1.5- to 3.5-ml aliquots of condensate were transferred to Eppendorf tubes and immediately frozen. Exhaled breath was collected before, and 10, 30, and $60 \mathrm{~min}$, and 6 and $24 \mathrm{~h}$ after exercise. Samples were stored at $-80^{\circ} \mathrm{C}$ for $\leq 3$ months [14]. The samples were not concentrated prior to measurement. Measurements were performed in a blinded fashion, and samples were run in duplicate. Our preliminary study indicated that RANTES in EBC stored at $-80^{\circ} \mathrm{C}$ remains stable for $\geq 3$ months with good reproducibility.

RANTES in Exercise-Induced Bronchoconstriction
Serum total IgE and ECP concentrations were measured using ImmunoCAP ${ }^{\mathrm{TM}}$ Technology (Pharmacia Diagnostics, Uppsala, Sweden). Blood eosinophils were counted using a hematologic analyzer (Coulter Electronics, Miami, Fla., USA). Concentrations of RANTES (R\&D Systems, Wiesbaden-Nordenstadt, Germany) in EBC were determined using an enzyme-linked immunosorbent assay. The minimum dose detectable was $2.0 \mathrm{pg} / \mathrm{ml}$.

\section{Analysis}

Statistical significance was analyzed by analysis of variance followed by Bonferroni's t test post hoc to determine statistical differences. All values were expressed as means $\pm \mathrm{SD} ; \mathrm{p}<0.05$ was considered significant. $\mathrm{PC}_{20}$ values were logarithmically transformed for analysis. Associations among the parameters studied were assessed using Pearson's linear correlation coefficient.

\section{Results}

Characteristics of the asthmatic and healthy volunteer groups are shown in table 1 . Eleven patients of the asthmatic group had a positive and 8 had a negative exercise test. In none of the healthy volunteers were spirometric parameters worse after exercise.

Blood eosinophilia, serum ECP, baseline $\mathrm{F}_{\mathrm{ENO}}$ and total IgE were statistically significantly higher in both asthmatic subgroups than in healthy volunteers. In the subgroup of patients with EIB, serum ECP concentrations 


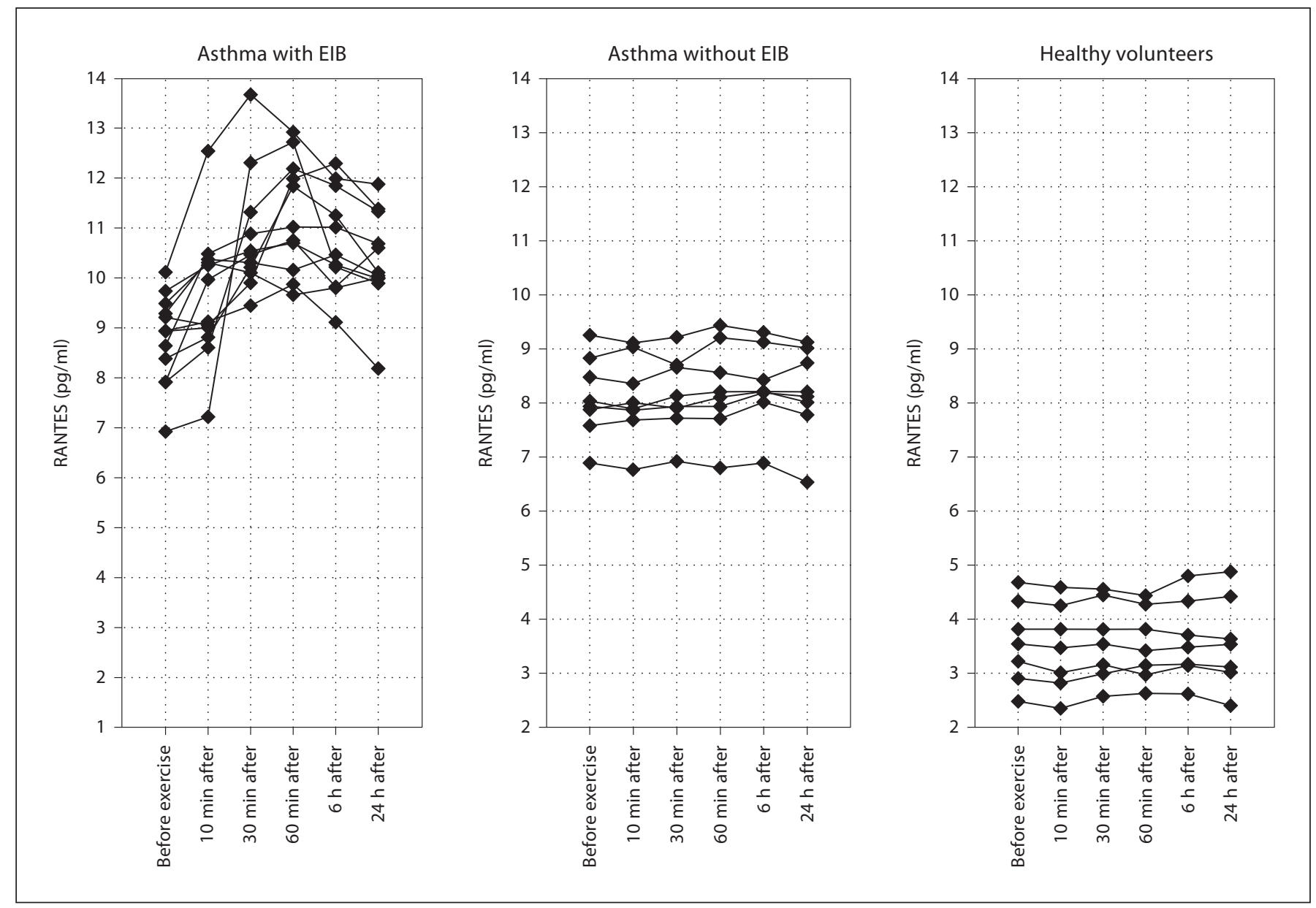

Fig. 1. Concentrations of RANTES in EBC at rest and concentration changes observed during the $24 \mathrm{~h}$ after exercise in asthmatic patients and healthy volunteers.

were significantly raised compared to patients without EIB; blood eosinophil counts, serum levels of total IgE and baseline $\mathrm{F}_{\mathrm{ENO}}$ were also higher, but these differences were not statistically significant.

RANTES in EBC was statistically significantly elevated in all asthmatic patients compared with healthy controls $(8.47 \pm 0.90$ vs. $3.56 \pm 0.76 \mathrm{pg} / \mathrm{ml}, \mathrm{p}<0.001)$. There was no statistically significant difference in the concentration of RANTES in EBC before exercise between asthmatics with and without EIB (8.76 \pm 0.93 vs. $8.08 \pm 0.73$ $\mathrm{pg} / \mathrm{ml}, \mathrm{p}=0.24)$. In the group of healthy controls, RANTES levels in the EBC were statistically significantly decreased compared with asthmatics (asthma with EIB vs. healthy volunteers: $3.56 \pm 0.76 \mathrm{pg} / \mathrm{ml}, \mathrm{p}<0.001$; asthma without EIB vs. healthy volunteers: $p<0.001$ ).

A statistically significant increase in the concentration of RANTES in asthmatic patients with EIB was noted $(\mathrm{p}<0.001 ; 10 \mathrm{~min}$ after exercise: $9.69 \pm 1.37 \mathrm{pg} / \mathrm{ml}, \mathrm{p}=$ 0.016; $30 \mathrm{~min}$ after exercise: $10.82 \pm 1.21 \mathrm{pg} / \mathrm{ml}, \mathrm{p}=$ 0.004; $60 \mathrm{~min}$ after exercise: $11.26 \pm 1.12 \mathrm{pg} / \mathrm{ml}, \mathrm{p}=$ 0.002; $6 \mathrm{~h}$ after exercise: $10.72 \pm 1.03 \mathrm{pg} / \mathrm{ml}, \mathrm{p}=0.001$; $24 \mathrm{~h}$ after exercise: $10.37 \pm 0.99 \mathrm{pg} / \mathrm{ml}, \mathrm{p}=0.003)$. Exercise did not affect the concentrations of RANTES in EBC in either asthmatic patients without EIB $(\mathrm{p}=0.99)$ or healthy volunteers ( $\mathrm{p}=0.99$; fig. 1 ).

The changes in RANTES in EBC were absent after BPT with histamine (patients with EIB: before BPT with histamine $8.89 \pm 0.81 \mathrm{pg} / \mathrm{ml}, 60 \mathrm{~min}$ after $8.67 \pm 0.91$ $\mathrm{pg} / \mathrm{ml}, 24 \mathrm{~h}$ after $8.76 \pm 0.93 \mathrm{pg} / \mathrm{ml}$; patients without EIB: before BPT with histamine $7.96 \pm 0.81 \mathrm{pg} / \mathrm{ml}, 60 \mathrm{~min}$ after $7.81 \pm 0.93 \mathrm{pg} / \mathrm{ml}, 24 \mathrm{~h}$ after $8.08 \pm 0.73 \mathrm{pg} / \mathrm{ml}$ ).

The maximum increase in RANTES after exercise significantly correlates with the baseline level of RANTES in $\operatorname{EBC}(\mathrm{r}=0.5, \mathrm{p}=0.01)$. There were no statistically sig- 
Fig. 2. Changes in $\mathrm{F}_{\mathrm{ENO}}$ levels $24 \mathrm{~h}$ after exercise in asthmatic patients.
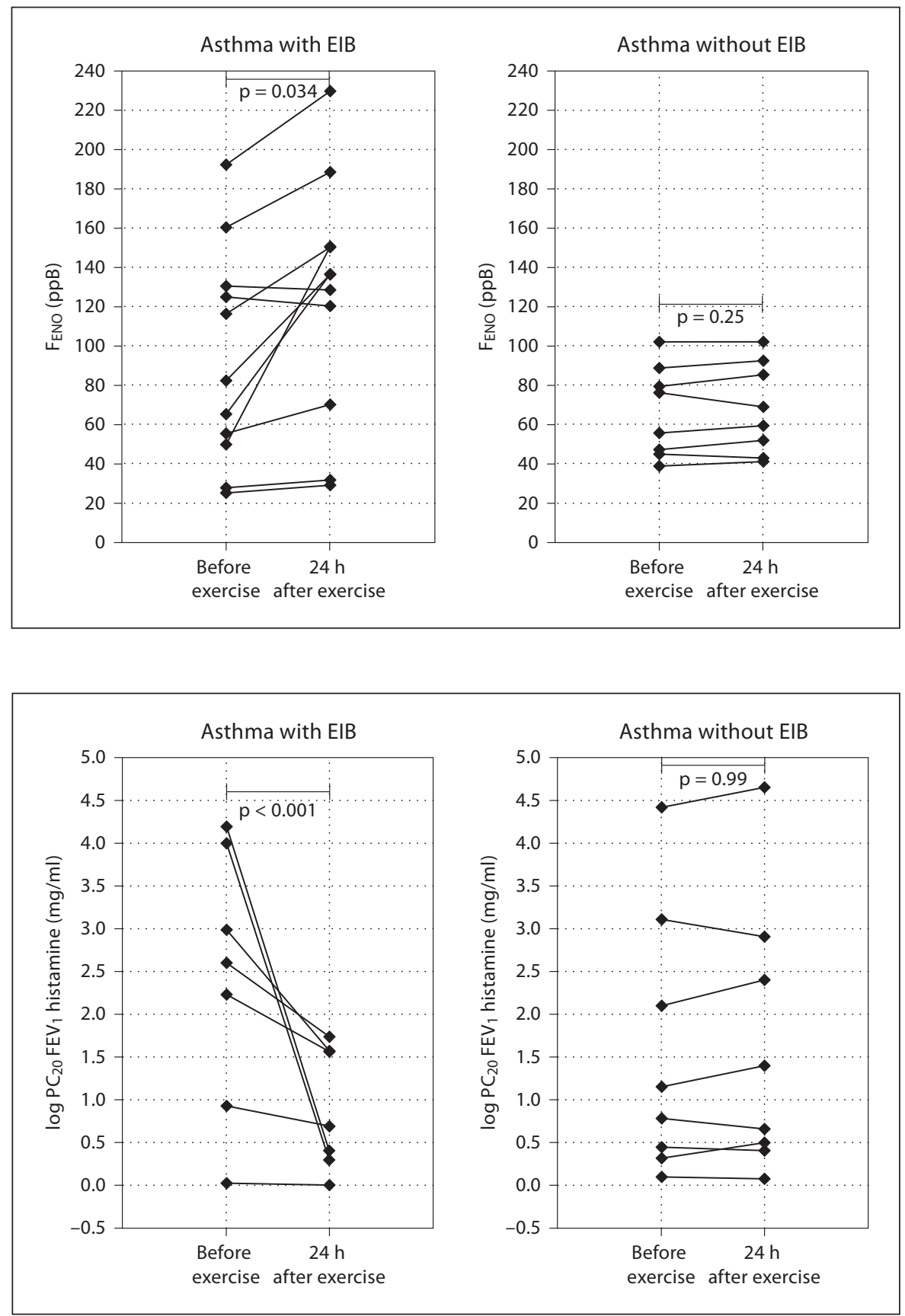

Fig. 3. Changes in BHR to histamine expressed as the histamine $\log \mathrm{PC}_{20} 24 \mathrm{~h}$ after exercise in asthmatic patients. $\left(\log \mathrm{PC}_{20} \mathrm{FEV}_{1}\right.$ before exercise: $-0.59 \pm 1.16 \mathrm{pg} / \mathrm{ml} ; 24 \mathrm{~h}$ after exercise: $-0.95 \pm 1.03 \mathrm{pg} / \mathrm{ml} ; \mathrm{p}<0.001)$ were statistically significantly increased $24 \mathrm{~h}$ after exercise but not in the asthmatics without $\mathrm{EIB}$ ( $\mathrm{F}_{\mathrm{ENO}}$ before exercise: 66.62 $\pm 23.05 \mathrm{ppB} ; 24 \mathrm{~h}$ after exercise: $67.87 \pm 23.03 \mathrm{ppB} ; \mathrm{p}=$ 0.25; $\log \mathrm{PC}_{20} \mathrm{FEV}_{1}$ before exercise: $-0.053 \pm 0.55 \mathrm{mg} /$ $\mathrm{ml} ; 24 \mathrm{~h}$ after exercise: $-0.0511 .62 \pm 0.59 \mathrm{mg} / \mathrm{ml} ; \mathrm{p}=0.99$; fig. 2, 3). 
Fig. 4. Changes in serum ECP levels $24 \mathrm{~h}$
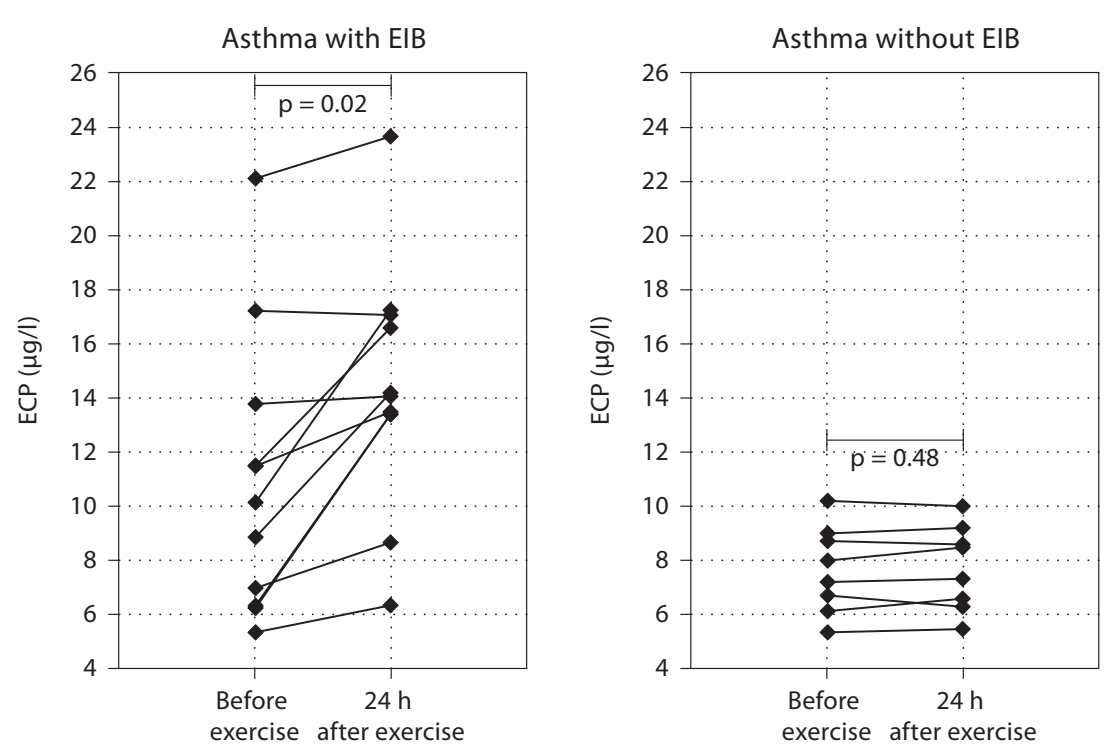

after exercise in asthmatic patients.

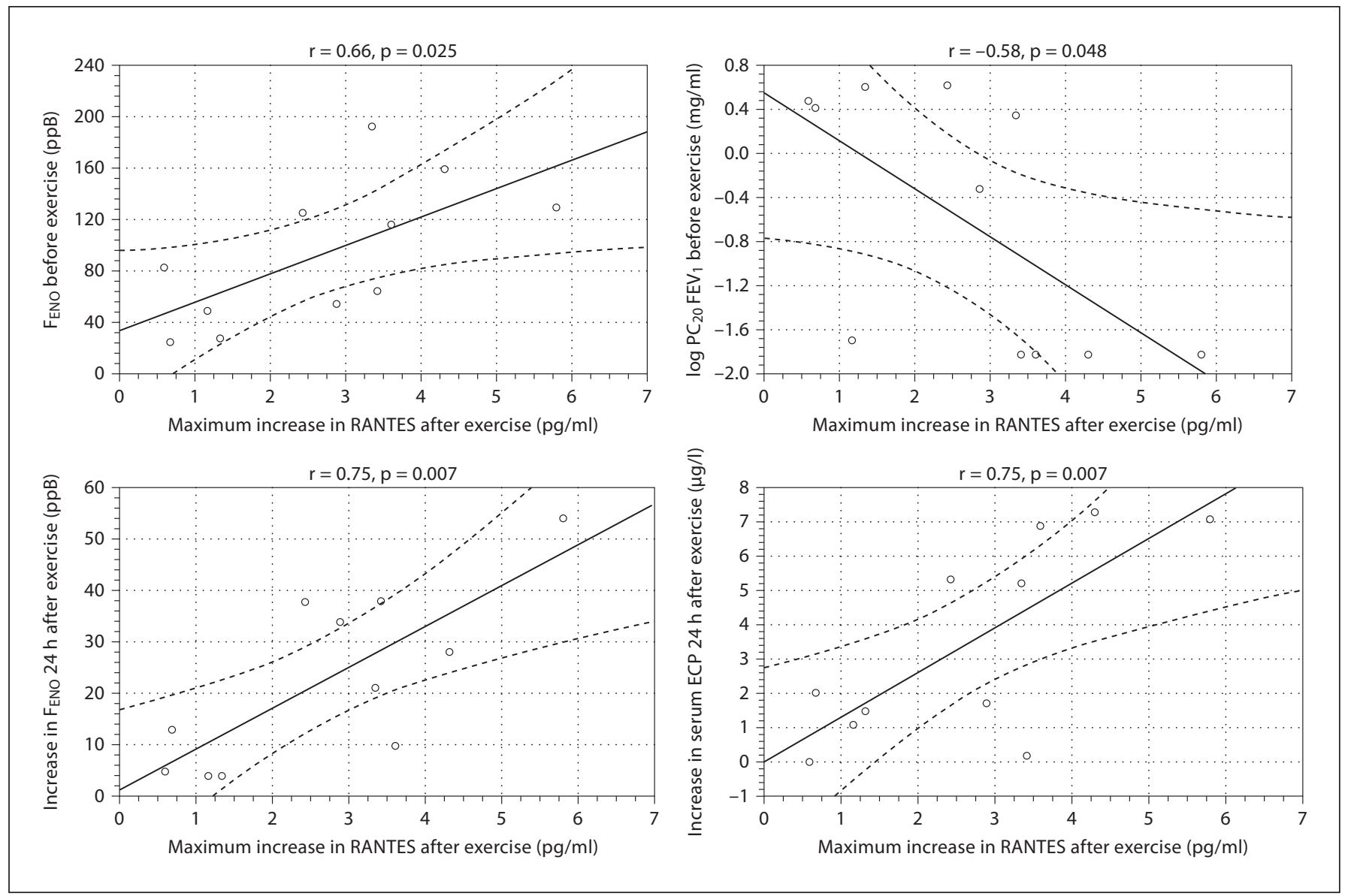

Fig. 5. Correlations between the maximum increase in RANTES in EBC and either baseline $\mathrm{F}_{\mathrm{ENO}}$ and baseline $\mathrm{BHR}$ to histamine or changes in $\mathrm{F}_{\mathrm{ENO}}$ and serum ECP $24 \mathrm{~h}$ after exercise in the asthmatics with EIB. 
In the asthmatics with EIB, there was a statistically significant increase in serum ECP concentrations $24 \mathrm{~h}$ after exercise (before exercise: $10.88 \pm 5.18 \mu \mathrm{g} / \mathrm{l} ; 24 \mathrm{~h}$ after exercise: $14.35 \pm 4.52 \mu \mathrm{g} / \mathrm{l} ; \mathrm{p}=0.02$ ), which was absent in the asthmatics without EIB (before exercise: $7.64 \pm 1.63 \mu \mathrm{g} / \mathrm{l}$; $24 \mathrm{~h}$ after exercise: $7.72 \pm 1.57 \mu \mathrm{g} / \mathrm{l} ; \mathrm{p}=0.48$; fig. 4 ).

Peripheral blood eosinophilia was not significantly different $24 \mathrm{~h}$ after exercise. Significant changes in FEV were also not detected in the asthmatic subgroups $24 \mathrm{~h}$ after exercise.

A statistically significant correlation between the maximum increase in RANTES concentrations in EBC after exercise and either baseline $\mathrm{F}_{\mathrm{ENO}}(\mathrm{r}=0.66, \mathrm{p}=0.025)$ or baseline BHR to histamine (expressed as log $\mathrm{PC}_{20}$ $\left.\mathrm{FEV}_{1} ; \mathrm{r}=-0.58, \mathrm{p}=0.048\right)$ and the increase in $\mathrm{F}_{\mathrm{ENO}}(\mathrm{r}=$ $0.75, \mathrm{p}=0.007)$ or serum ECP $(\mathrm{r}=0.75, \mathrm{p}=0.007) 24 \mathrm{~h}$ after exercise was found in the subgroup of asthmatics with EIB (fig. 5).

\section{Discussion}

The pathogenesis of EIB in asthma and the role of chemokines in this process are incompletely understood. It has been proposed that the release of mediators such as histamine, leukotrienes and prostanoids from mast and epithelial cells in response to a hyperosmolar stimulus may be responsible for the bronchospasm [22]. The results of studies concerning the role of inflammatory mediators in EIB are conflicting. However, it has been suggested that inflammatory processes are involved in the pathogenesis of EIB [23].

Results of our previous studies indicate that platelet activation, and the increase in RANTES release probably related to this activation, could be one of the factors triggering increased airway inflammation following EIB in asthmatic patients [13].

Eosinophils are the key inflammatory cells in asthma, but their role in EIB remains to be elucidated $[4,24]$. In a study by Gauvreau et al. [25], exercise had no effect on inflammatory cells assessed in the blood or sputum. Koh and Choi [26] reported that the severity of EIB correlates with peripheral blood eosinophilia, and that the blood eosinophil count was a significant predictor of EIB. Venge et al. [27] have shown that serum ECP reflects the degree of EIB in asthma patients. The role of eosinophils in EIB was described by Kivity et al. [28], who demonstrated significantly increased sputum eosinophil counts in EIB patients, but not in those without EIB or after BPT with methacholine.
RANTES, a CCL chemokine, is produced by endothelial cells, fibroblasts, T lymphocytes, eosinophils, platelets, bronchial epithelial cells, mast cells and other cells [29]. It is a powerful chemoattractant of inflammatory cells, particularly eosinophils and T lymphocytes [29], which also activates these immune cells and induces the exocytosis of bronchoconstrictive mediators [29]. Therefore, RANTES might be involved in inflammatory cell recruitment and the induction of bronchoconstrictive mediator release from cells resulting in airflow limitation.

In a study by Tahan et al. [30] in children, chemokine profiles were not significantly different following EIB. However, they pointed out somelimitations of their study. The chemokine measurements were performed in the systemic circulation and therefore may not reflect changes occurring in the bronchial epithelium after exercise. The authors also suggested that these changes could not be excluded in case of more pronounced exercise responses than those observed in their patients, since previous studies demonstrated that systemic chemokine levels may change after marathon running [8].

In our study, we aimed to assess changes in RANTES concentrations in EBC which may result from the increased expression of this cytokine in asthmatic airways following intensive exercise in asthmatics and to investigate possible correlations between this parameter and the results of other measurements commonly associated with asthmatic inflammation.

The lining fluid of the respiratory tract contains various nonvolatile and $>200$ volatile substances. EBC is a means to collect respiratory secretions. EBC analysis is a noninvasive tool to determine mediator levels in the airways. EBC is simple to perform, rapid and effort independent, even in children and patients with asthma exacerbation. This type of sampling can be repeated in short intervals without side effects. It provides an opportunity to follow changes in mediator levels in the airways during exercise challenge. EBC collection does not alter airway function or inflammation. Mediator levels in EBC are more variable than EBC volume, but good reproducibility has been reported for adenosine, aldehyde, glutathione, leukotriene and pH levels in EBC [21].

In previous studies on asthmatic patients, inflammatory mediators such as adenosine and Cys-LT were elevated in EBC during exercise. Csoma et al. [31] revealed a pronounced increase in adenosine levels in EBC during EIB in asthmatic patients, and a relationship between this increase and the degree of bronchospasm was observed. Carraro et al. [32] noted higher EBC Cys-LT levels in 
asthmatic children with EIB, which correlated with the decrease in $\mathrm{FEV}_{1}$ after exercise. We also found a significant increase in endothelin-1 levels in EBC collected between $10 \mathrm{~min}$ and $6 \mathrm{~h}$ after exercise [33].

In our study, the highest baseline concentration of RANTES was observed in asthmatic patients with EIB. However, statistically significant changes in the levels of this parameter were demonstrated only in comparison with the group of healthy volunteers. Only the subgroup of patients with EIB had a statistically significant increase in RANTES levels in EBC collected between 10 min and $24 \mathrm{~h}$ after exercise. The maximum increase in RANTES levels was correlated with baseline BHR to histamine and baseline $\mathrm{F}_{\mathrm{ENO}}$ levels - which has become a more and more noticeable criterion for the evaluation of eosinophilic inflammation in the airways [34] - as well as with the increase in $\mathrm{F}_{\mathrm{ENO}}$ or serum ECP levels $24 \mathrm{~h}$ after exercise.

It cannot be excluded that RANTES in EBC originates from the circulating blood. However, the correlation of RANTES levels in EBC with the changes in the other parameters and the relationship between this cytokine and the inflammatory process, involving RANTES release by several cell types, possibly imply that fluctuations in the concentrations of this cytokine after exercise may be a consequence of increased RANTES expression in asthmatic airways. A possible limitation of our study could be the small number of asthmatics and healthy volunteers; therefore, the results of this study have to be confirmed by future studies including larger patient cohorts.

\section{Conclusion}

This study was performed to assess the possible role of RANTES in the pathogenesis of EIB, particularly during the inflammatory process. EIB results in increased RANTES levels in EBC. Consequently, increased RANTES expression in asthmatic airways, via inflammatory cell recruitment and bronchoconstrictive mediator release, may play an important role in the upregulation of airway inflammation following EIB in asthmatic patients, but not in asthmatics without EIB. Appropriate anti-inflammatory treatment could protect asthmatic patients from EIB and, as a consequence, from increasing airway inflammation.

\section{Acknowledgments}

We would like to thank all the study participants. This work was supported by research grant No. 3-35523P from the Medical University of Bialystok, Poland.

\section{References}

1 Lee SY, Kim HB, Kim JH, Kim BS, Kang MJ, Jang SO, Hong SJ: Eosinophils play a major role in the severity of exercise-induced bronchoconstriction in children with asthma. Pediatr Pulmonol 2006;41:1161-1166.

$\checkmark 2$ Peroni DG, Boner AL: Exercise-induced asthma: is there space for late-phase reactions? Eur Respir J 1996;9:1335-1338.

$\checkmark 3$ Pods R, Ross D, van Hulst S, Rudack C, Maune S: RANTES, eotaxin and eotaxin-2 expression and production in patients with aspirin triad. Allergy 2003;58:1165-1170.

-4 Busse WW, Lemanske RF Jr: Asthma. N Engl J Med 2001;344:350-362.

5 Miotto D, Christodoulopoulos P, Olivenstein R, Taha R, Cameron L, Tsicopoulos A, Tonnel AB, Fahy O, Lafitte JJ, Luster AD, Wallaert B, Mapp CE, Hamid Q: Expression of INF- $\gamma$-inducible protein; monocyte chemotactic proteins 1,3 , and 4 ; and eotaxin in $\mathrm{T}_{\mathrm{H}} 1$ - and $\mathrm{T}_{\mathrm{H}} 2$-mediated lung diseases. J Allergy Clin Immunol 2001;107:664-670.

6 Luster AD: Chemokines: chemotactic cytokines that mediate inflammation. $\mathrm{N}$ Engl J Med 1998;338:436-445.

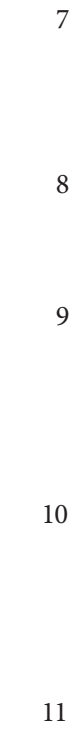

Ostrowski K, Hermann C, Bangash A, Schjerling P, Nielsen JN, Pedersen BK: A trauma-like elevation of plasma cytokines in humans in response to treadmill running. J Physiol 1998;513:889-894.

8 Ostrowski K, Rohde T, Asp S, Schjerling P, Pedersen BK. Chemokines are elevated in plasma after strenous exercise in humans. Eur J Appl Physiol 2001;84:244-245.

9 Hashimoto S, Matsumoto K, Gon Y, Nakayama T, Takeshita I, Horie T: Hyperosmolarityinduced interleukin-8 expression in human bronchial epithelial cells through p38 mitogen-activated protein kinase. Am J Respir Crit Care Med 1999;159:634-640.

10 Gon Y, Hashimoto S, Matsumoto K, Nakayama T, Takeshita I, Horie T: Cooling and rewarming-induced IL-8 expression in human bronchial epithelial cells through p38 MAP kinase-dependent pathway. Biochem Biophys Res Commun 1998;249:156-160.

11 Crimi E, Balbo A, Milanese M, Miadonna A, Rossi GA, Brusasco V: Airway inflammation and occurrence of delayed bronchoconstriction in exercise-induced asthma. Am Rev Respir Dis 1992;146:507-512.
12 Yoshikava T, Shoji S, Fujii T, Kanazawa H, Kudoh S, Hirata K, Yoshikawa J: Severity of exercise-induced bronchoconstriction is related to airway eosinophilic inflammation in patients with asthma. Eur Respir J 1998;12: 879-884.

13 Zietkowski Z, Bodzenta-Lukaszyk A, Tomasiak MM, Skiepko R, Mroczko B, Szmitkowski M: Changes in RANTES and $\beta$ thromboglobulin after intensive exercise in patients with allergic asthma. Int Arch Allergy Immunol 2009;148:31-40.

14 Horvath I, Hunt J, Barnes PJ: Exhaled breath condensate: methodological recommendations and unresolved questions. Eur Respir J 2005;26:523-548.

- 15 Matsunaga K, Yanagisava S, Ichikava T, Ueshima K, Akamatsu K, Hirano T, Nakanishi M, Yamagata T, Minakata Y, Ichinose M: Airway cytokine expression measured by means of protein array in exhaled breath condensate: correlation with physiologic properties in asthmatic patients. J Allergy Clin Immunol 2006;118:84-90. 
16 Global Initiative for Asthma. Global Strategy for Asthma Management and Prevention. NHLBI/WHO Report 2002, publication 023569.

17 American Thoracic Society/American Lung Association: Recommendations for standardized procedures for the on-line and offline measurement of exhaled lower respiratory nitric oxide and nasal nitric oxide in adults and children-1999. This official statement of the American Thoracic Society was adopted by the ATS Board of Directors, July 1999. Am J Respir Crit Care Med 1999;160: 2104-2117.

18 American Thoracic Society: Lung function testing: selection of reference values and interpretative strategies. Am Rev Respir Dis 1991;144:1202-1218.

-19 Ryan G, Dolovich MB, Roberts RS, Frith PA, Juniper EF, Hargreave FE, Newhouse MT: Standardization of inhalation provocation tests: two techniques of aerosol generation and inhalation compared. Am Rev Respir Dis 1981;123:195-199.

-20 Eggleston PA: Methods of exercise challenge. J Allergy Clin Immunol 1984;73:666-669.

21 Rahman I, Biswas S: Non-invasive biomarkers of oxidative stress: reproducibility and methodological issues. Redox Rep 2004;9: 125-143.
22 Eggleston PA, Kagey-Sobotka A, Lichtenstein LM: A comparison of the osmotic activation of basophils and human lung mast cells. Am Rev Respir Dis 1987;135:10431048.

23 Hallstrand TS, Moody MW, Wurfel MM, Schwartz LB, Henderson WR, Aitken ML: Inflammatory basis of exercise-induced bronchoconstriction. Am J Respir Crit Care Med 2005;172:679-686.

24 Bartoli ML, Di Franco A, Vagaggini B, Bacci E, Cianchetti S, Dente FL, Tonelli M, Paggiaro PL: Biological markers in induced sputum of patients with different phenotypes of chronic airway obstruction. Respiration 2009;77:265-272.

25 Gauvreau GM, Ronnen GM, Watson RM, O’Bryne PM: Exercise-induced bronchoconstriction does not cause eosinophilic airway inflammation or airway hyperresponsiveness in subjects with asthma. Am J Respir Crit Care Med 2000;162:1302-1307.

26 Koh YI, Choi S: Blood eosinophil counts for the prediction of the severity of exercise-induced bronchospasm in asthma. Respir Med 2002;96:120-125.

27 Venge P, Henriksen J, Dahl R: Eosinophils in exercise-induced asthma. J Allergy Clin Immunol 1991;88:699-704.

28 Kivity S, Argaman A, Onn A, Shwartz Y, Man A, Greif J, Fireman E: Eosinophil influx into the airways in patients with exercise-induced asthma. Respir Med 2000;94:12001205.
29 Chung KF, Barnes PJ: Cytokines in asthma. Thorax 1999;54:825-857.

30 Tahan F, Karaaslan C, Aslan A, Kiper N, Kalacyi $\mathrm{O}$ : The role of chemokines in exerciseinduced bronchoconstriction in asthma. Ann Allergy Asthma Immunol 2006;96: 819-825.

-31 Csoma Z, Huszar E, Vizi E, Vass G, Szabo Z, Herjavecz I, Kollai M, Horvath I: Adenosine level in exhaled breath increases during exercise-induced bronchoconstriction. Eur Respir J 2005;25:873-878.

32 Carraro S, Corradi M, Zanconato S, Alinovi R, Pasquale MF, Zacchello F, Baraldi E: Exhaled breath condensate cysteinyl leukotrienes are increased in children with exerciseinduced bronchoconstriction. J Allergy Clin Immunol 2005;115:764-770.

33 Zietkowski Z, Skiepko R, Tomasiak MM, Bodzenta-Łukaszyk A: Endothelin-1 in exhaled breath condensate of allergic asthma patients with exercise-induced bronchoconstriction. Respir Res 2007;8:76.

34 Smith AD, Cowan JO, Filsell S, McLachlan C, Monti-Sheehan G, Jackson P, Taylor DR: Diagnosing asthma. Comparisons between exhaled nitric oxide measurements and conventional tests. Am J Respir Crit Care Med 2004;169:473-478. 